\title{
The South African Redistribution Imperative: Incongruities in Theory and Practice
}

\author{
Sue-Mari Viljoen*
}

University of the Western Cape, Cape Town, South Africa

suviljoen@uwc.ac.za

\begin{abstract}
It has partly been assumed that the constitutional obligation to pay compensation for expropriations is to blame for the slow pace at which land has been redistributed in South Africa. However, this assumption requires careful analysis and reflection, with reference to the imperfections of the policies and laws that set out to address landlessness, as well as the underlying theoretical approach to economic justice. This article questions the purpose for which land reform beneficiaries acquire land, with reference to the role that property should ideally fulfil for the landless. The article makes a number of observations to cast light on why the redistribution of land has been alarmingly slow, where inconsistencies and loopholes exist in the programme, and whether expropriations for nil compensation will make any difference in remedying existing failures in the redistribution programme.
\end{abstract}

\section{Keywords}

South Africa, land reform, redistribution, economic justice, egalitarianism, property theory

\section{INTRODUCTION}

Section 25 (the Property Clause) of the Constitution of the Republic of South Africa, 1996 (the Constitution) is widely known to serve a dual function: to protect property rights and allow for the regulation of such rights to meet societal goals, including land reform. The redistribution of land is one of the land reform programmes and mandates the government to widen access to land for the previously disadvantaged. Redistribution is intended to redress injustices of the past and enable previously dispossessed households to establish thriving livelihoods. An important measure the state can use to acquire suitable land for this constitutional imperative is the power to expropriate property. Strangely, a distressingly limited number of properties have in fact been

Associate professor, Department of Private Law, University of the Western Cape. The author would like to thank the reviewers for their helpful comments and suggestions. All views and errors remain the author's. 
expropriated and distributed for this goal; the reasons remain obscure. The proposed constitutional amendment of the Property Clause implies that the constitutional obligation to pay compensation for expropriation is, at least partly, to blame for the slow pace at which land reform, specifically redistribution, has been implemented. A politically driven proposition of allowing expropriations for nil compensation, specifically for land reform purposes, was subsequently initiated and further fleshed out in legislative proposals, in an attempt to rectify the unmistaken failure of land reform.

In the redistribution context, this presumption requires careful analysis and reflection, with reference not only to the imperfections of the policies and laws that seemingly set out to address landlessness, but also the underlying theoretical approach to both economic justice and property as an enabling mechanism. It should be stressed that the South African redistribution commitment is a crucial measure not only for resource allocation but also for wealth distribution. Drawing from theories of economic justice, this article scrutinizes the state's approach to this constitutional imperative by critically analysing the laws and policies that are relevant to the programme, with special emphasis on the acquisition of land. The article also questions the purpose behind land reform beneficiaries acquiring land, with reference to the role that property should ideally fulfil in society, specifically for the vulnerable. Throughout this analysis, the article makes a number of observations to cast light on why the redistribution of land has been alarmingly slow, where incongruities and loopholes continue to exist in the programme, and whether expropriations for nil compensation will make any difference in remedying existing failures.

\section{AN EGALITARIAN APPROACH TO DISTRIBUTIVE JUSTICE?}

It is generally accepted that land reform not only entails resource allocation in agriculture through the redistribution of land, but also "changes the distribution of income and wealth in the economy as a whole". ${ }^{1}$ The proper distribution of wealth has been described as a fundamental public concern. The approach towards the distribution of wealth, including resources, can generally be described as either egalitarian or libertarian. In terms of the former, economic assets should be distributed in an equal manner, ${ }^{2}$ whereas, in terms of the latter, economic assets should circulate through free transaction. Both these approaches allow for exceptions. ${ }^{3}$ Grey explains that, even though one could describe a range of positions from extreme libertarian to extreme egalitarian along a single continuum, which might create the impression that there is no real difference between the two schools, such a description

1 E Flores "The economics of land reform" (1965) 92 International Labour Review 21 at 30.

2 D Markovits "How much redistribution should there be?" (2003) 112 Yale Law Journal 2291 at 2291.

3 TC Grey "Property and need: The welfare state and theories of distributive justice" (1976) 28 Stanford Law Review 877 at 877. 
would likely obscure real and important differences between the two approaches. ${ }^{4}$ He explains:

\begin{abstract}
"In questions of ethics and public policy as in questions of law, it is always important - and surprisingly often determinative - which way the presumption lies, who has the burden of proof. Rarely does anyone approach the question of economic justice without a working presumption. To an egalitarian, the presumption is for equality. To a libertarian the presumption is for liberty. Here the first question is the extent and nature of coercive interference with voluntary transactions and their fruits, and the burden is on him who would justify such coercion. The differences in starting point correspond more often than not with different judgments on concrete issues of policy, and they may often reflect ultimate differences in world view." ${ }^{5}$
\end{abstract}

One of the most profound writings on economic justice, from a qualified egalitarian perspective, is John Rawls's A Theory of Justice, ${ }^{6}$ in which he sets out a hierarchy of three principles as limitations on the operation of social and political institutions. ${ }^{7}$ These are: the principle of liberty (protecting basic freedoms, such as speech and religion); the principle of equal opportunity (both forbidding class barriers and promoting affirmative action); and the "difference" principle, which deals with economic distribution. ${ }^{8}$ According to the difference principle, economic assets should be distributed in such a way that maximizes the position of the poorest segment of society. This means that wealth should be distributed equally, "except insofar as unequal distribution will give the poorest group more in the long run than they would have under complete equality". ${ }^{9}$ However, redistribution can only be justified to the extent that it does not conflict with the first and second principles, of basic liberties and equal opportunity. ${ }^{10}$

Interestingly, the difference principle should be implemented by way of a system of taxation and transfer payments, ${ }^{11}$ whereas the right to hold property is located under the first principle, which is hierarchically superior to the distribution mandate. Grey explains that "taxation for purposes of maximizing the economic position of the worst-off group is somehow not regarded as in conflict with property rights". ${ }^{12}$ Nevertheless, the nature of property rights in terms of the first principle is not entirely clear. What is clear is

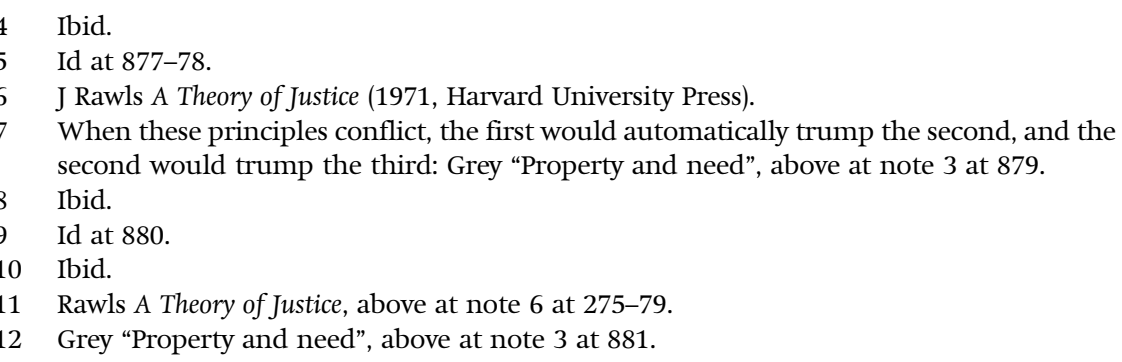


that the holding of assets by different people is judged with reference to their size in relation to one another; equal holdings are just, whereas unequal holdings are only just if the smallest of them is as large as it possibly could be, being mindful of the long-run. ${ }^{13}$

According to Rawls, the justification for requiring redistribution, founded on the difference principle, is that the aptitudes that tend to yield wealth in a fair market are inherently arbitrary from a moral perspective. ${ }^{14}$ Individuals' scarce talents or skills result in higher incomes, albeit accidentally, by way of social circumstances; it is therefore unjust to allow for such circumstances to produce unequal rewards, especially if they can be "corrected" without having to infringe basic liberties or equal opportunities. ${ }^{15}$ Any failure to distribute, until the position of the worst-off group is maximized, is itself unjust and a violation of human rights. ${ }^{16}$ Grey points out that an entitlement of this kind has little intuitive appeal as a value and is not necessarily supported by credible arguments founded on other values. ${ }^{17}$

For Grey, there are basically two arguments that could be made for redistribution in the absence of need: on the basis that "some degree of economic equality is a public good", and that some form of rectification or corrective justice is required to redress wrongdoing of the past, such as the taking of property by force. ${ }^{18}$ Interesting, and key to his contribution, is Grey's overview of a range of arguments that are made in favour of distribution for the poor and conclude that a right exists in each person "to have his basic material needs met by his society to the extent he is unable to meet them by his own efforts. This right is an important one, of justly held property". ${ }^{19}$

A right to basic material needs is additional to bare physical subsistence and quite different in the sense that the floor that it establishes is socially determined. In each society exists a moral consensus regarding the needs that must be fulfilled in order for a person to be treated as a free and "full" member of society; this standard will require different kinds and quantities of goods, depending on the specific society at a given point in time. ${ }^{20}$ Critical

13 Id at 882. In contrast, the status and defence of property rights is a central theme in $\mathrm{R}$ Nozick Anarchy, State and Utopia (1974, Basic Books), which is widely known to offer a more radical libertarian view on economic justice. Nozick questions the underlying principles of "distributive justice" by stating (at 149) that "there is no central distribution, no person or group entitled to control all the resources, jointly deciding how they are to be doled out".

14 Rawls A Theory of Justice, above at note 6 at 72.

15 Grey "Property and need", above at note 3 at 883-84. See also criticism raised by Nozick Anarchy, State and Utopia, above at note 13 at 214.

16 Grey, id at 886.

17 Ibid.

18 Id at 887.

19 Id at 897.

20 Id at 898. The South African Constitution does not describe in any detail the content of the needs that should be fulfilled in the context of either land or housing. Legislative measures should arguably fill this void, although the analysis below clearly shows that 
to Grey's argument is the requirement that there must exist "some substantial degree of social consensus as to what are the basic needs, at what level they must be met to sustain basic self-respect, and what constitutes being involuntarily unable to meet them through one's own efforts". ${ }^{21}$ Even though there might be consensus at the level of a widely shared general conception in a given society, disagreements within this "consensus" will still be substantial in relation to actual necessities, in addition to "disagreements over what people can reasonably be expected to do in support of themselves before calling on collective resources". ${ }^{22}$ More specifically, Cohen suggests that the purpose of egalitarianism is to "eliminate involuntary disadvantage," which he explains as "disadvantage for which the sufferer cannot be held responsible" due to the fact that it does not reflect his or her choice. ${ }^{23}$ Society should therefore indemnify individuals against prejudicial outcomes that are caused beyond their control, but not against those that are within their control, for which they are responsible. ${ }^{24} \mathrm{~A}$ number of egalitarians have adopted such a responsibility-tracking approach, ${ }^{25}$ which not only converges on how much redistribution there should be, but is also "connected to an intuitively powerful conception of $\ldots$ the ideal of the non-subordination of persons". ${ }^{26}$ Markovits explains that, when distribution takes place in the form of taking from those who have chosen well to compensate others for the unfortunate consequences of their bad choices, the former group of persons are effectively subordinated to the latter. ${ }^{27}$

In South Africa, where land reform is not only a symbol of reconciliation but also a vehicle for wealth distribution, a redundant question might be whether an egalitarian approach has in fact been adopted throughout the redistribution discourse? The presumption would be in the affirmative, because the Constitution has been interpreted, on more than one occasion, to be founded on egalitarian principles. The Constitutional Court has held that the Constitution is intended to represent "a decisive break from, and a ringing rejection of, that part of the past which is disgracefully racist, authoritarian, insular, and repressive and a vigorous identification of and commitment to a democratic, universalistic, caring and aspirationally

contd

there is no consensus in the redistribution discourse on what households' bare occupation needs are; a threshold right to land or any form of space to reside on has not been explored as a right that is essential to human dignity. It should be noted that a minimum core obligation regarding housing was rejected outright in Government of the Republic of South Africa $v$ Grootboom 20011 SA 46 (CC).

Grey "Property and need", above at note 3 at 899.

Ibid.

GA Cohen "On the currency of egalitarian justice" (1989) 99 Ethics 906 at 916.

J Roemer "A pragmatic theory of responsibility for the egalitarian planner" (1993) 22 Philosophy and Public Affairs 146 at 147.

Markovits "How much redistribution", above at note 2 at 2297.

Ibid.

Ibid. 
egalitarian ethos". ${ }^{28}$ Moreover, the achievement of substantive equality, in terms of the equality clause, includes the assurance that everyone can "enjoy the benefits of an egalitarian ... society". ${ }^{29}$ That being so, the working presumption in the context of distributive justice ${ }^{30}$ should be in favour of the truly equal distribution of land, more so than free trade. If we opt for the former, is there a consensus as to each person's entitlement and which basic material needs must be met by society to enable the previously disadvantaged to thrive as participating members of society?

If this redistribution imperative can be rephrased as a right to justly held property or land, does it mean that property is a central, keystone right, especially in relation to other constitutional rights? Before tackling this question, a number of concerns relating to the South African redistribution imperative should be highlighted. Even though the presumption is for an egalitarian approach towards the distribution of land, a detailed analysis of the redistribution programme, taking account of the relevant policies and laws, suggests otherwise. ${ }^{31}$ It is highly questionable whether the redistribution programme is geared to allow for the equal distribution of land, more so than to promote free trade. With reference to the redistribution programme, it is unlikely that we have any consensus as to what the basic needs are, what should be distributed and how much land should be allocated to beneficiaries, in order for households to sustain self-respect and live with dignity. An underlying, yet central, question in the South African distributive justice discourse is therefore why the redistribution of property, and more specifically land, is a core constitutional objective. ${ }^{32}$ Even though the constitutional mandate to redistribute land is clear, the purpose is not, especially with reference to the laws and policies that make provision for it. ${ }^{33}$ of course, part and parcel of the entire land reform directive is the aim of redressing injustices of the past, but restorative justice in itself fails to describe why it is important for land to be distributed among beneficiaries, what function the institution of property has to fulfil, and how that impacts our approach to the redistribution imperative.

\section{THE PROPERTY PURPOSE}

For Adam Smith, a central objective of governance is to protect people in what is theirs. ${ }^{34}$ This centrality of property was emphasized by his contemporary, Arthur Lee, who stated that property is "the guardian of every other

$28 S v$ Makwanyane 19953 SA 391 (CC), para 262.

29 Bhe $v$ Khayelitsha Magistrate 20051 SA 580 (CC), para 50.

30 For the purposes of this article, this simply refers to the socially just allocation of resources, specifically land.

31 See the detailed discussion below.

32 The governmental obligation to distribute land is captured in the Constitution, sec 25(5).

33 See the detailed discussion below.

34 A Smith (RL Meek et al, eds) Lectures on Jurisprudence (1978, Oxford University Press) at 5. 
right”. ${ }^{35}$ More recently, James Ely argued that property is not necessarily central, but rather equal, in status to all other constitutional rights. ${ }^{36}$ In contrast to these views, Jennifer Nedelsky opines that the security of property may be more of a deterrent than any help in securing individual rights, especially in a society where rights are approached from an egalitarian perspective. ${ }^{37}$ In light of these opposing views, Carol Rose questions the centrality of property as a keystone right, the right on which all others rest. ${ }^{38}$ She acknowledges that property is an important right for a number of reasons (it is undoubtedly an important element of personal autonomy and a central function in wealth creation), but she concludes that "the arguments for property's political centrality - its guardianship role over other rights - have not proved to be completely convincing to those concerned with constitutional ordering". ${ }^{39}$ Even though some of the arguments are old and contested, that does not mean that they are inconsequential or incorrect: ${ }^{40}$ they continue to shed light on the importance of property, and specifically land, from a distributive justice perspective.

The independence argument is crucial for this purpose. Central to the argument is the idea that holding property permits greater independence and autonomy, which enables individuals to make unfettered decisions in the political sphere. It follows that all political powers, and therefore all other rights, are consequently dependent on the right to property. ${ }^{41}$ Initially, the only form of property that fulfilled this purpose was "large and longstanding landownership", ${ }^{42}$ although the modern version of the argument is completely different in terms of what functions as a platform for the distribution of rights. According to the modern version, everyone should participate in the political order, for which they require "a secure baseline of property - and if necessary, this baseline must be secured by redistribution". ${ }^{33}$

The luxury-good argument puts forward the idea that property has an important economic role in making a society wealthier. This allows citizens to do more for themselves and their communities, while the government would also be enabled to attend properly to common enterprises, as well as the general welfare of the community. ${ }^{44}$ Furthermore, property and

35 A Lee An Appeal to the Justice and Interests of the People of Great Britain, in the Present Dispute with America (1775, James Rivington) at 14, quoted in CM Rose "Property as the keystone right" (1996) 71 Notre Dame Law Review 329 at 332.

36 JW Ely Jr The Guardian of Every Other Right: A Constitutional History of Property Rights (1992, Oxford University Press) at 26.

37 J Nedelsky Private Property and the Limits of American Constitutionalism: The Madisonian Framework and Its Legacy (1990, University of Chicago Press) at 261-62.

38 Rose "Property as the keystone", above at note 35 at 333.

39 Id at 362 (emphasis original).

40 Ibid.

41 Id at 345.

42 Ibid.

43 Id at 347.

44 Id at 358. 
prosperity are not sufficient for the enjoyment of other rights / liberties, but they are considered a necessary stepping stone to fulfilling such rights. ${ }^{45}$ However, it is questionable whether wealth itself can promote the kind of stability in which other rights may flourish? Even though some may have thought so, "no one has seemed completely confident, at least not without conscious effort to adjust for the material and moral consequence of inequality". 46

Progressive property law scholars generally argue that the protection of private property and the promotion of social welfare objectives, including large-scale redistributive efforts, are not necessarily in conflict with one another; instead, private property is important for human welfare and should therefore be distributed as widely as possible. ${ }^{47}$ The equitable distribution of property is therefore considered as important as the protection of existing holdings. ${ }^{48}$ Although the tension between property and social welfare continues to exist (some property must be taken from the haves and distributed to the have-nots), some balancing process should be established both to rationalize the choice between the conflicting interests and to minimize the resulting harm. ${ }^{49}$ According to Dagan, an "egalitarian conception of private property" is an expression of a collection of values (such as privacy, security and autonomy) that inherently involves the distribution, as well as retention, of wealth..$^{50}$ An egalitarian conception of property accepts and endorses the inherent tension of retention and distribution, requires an "ongoing commitment to dispersal of access", and insists that our property system should be designed in such a way that property is widely distributed to prevent the re-emergence of "pockets of illegitimately concentrated power". 51

The Property Clause is arguably a perfect example of what Dagan argues for: an inherent commitment towards both the retention and distribution of wealth. ${ }^{52}$ The redistribution imperative suggests that there must be an ongoing commitment to the dispersal of access to land and that land should be widely distributed to ensure that landholding is somehow equalized. ${ }^{53}$

45 Ibid.

46 Id at 361.

47 AJ van der Walt and S Viljoen "The constitutional mandate for social welfare: Systemic differences and links between property, land rights and housing rights" (2015) 18 Potchefstroom Electronic Law Journal 1035 at 1038.

48 BD Barros "Property and freedom" (2009) 4 New York University Journal of Law E Liberty 36 at 50-51; AR Amar "Forty acres and a mule: A republican theory of minimal entitlements" (1990) 13 Harvard Journal of Law \& Public Policy 37 at 37.

49 Van der Walt and Viljoen "The constitutional mandate", above at note 47 at 1038, referring to TW Merrill "Private property and public rights" in K Ayotte and HE Smith (eds) Research Handbook on the Economics of Property Law (2011, Edward Elgar) 75 at 98.

50 H Dagan "Takings and distributive justice" (1999) 85 Virginia Law Review 741 at 779.

51 Id at 781, quoting JW Singer and JM Beermann "The social origins of property" (1993) 6 Canadian Journal of Law and Jurisprudence 217 at 241-43.

52 See for instance Port Elizabeth Municipality $v$ Various Occupiers 2005 (1) SA 217 (CC), para 15.

53 Access to land should of course not be wrongly equated with landownership. Access to 
Does this mean that we have successfully adopted an egalitarian conception of private property? ${ }^{54}$ Regardless of the extent to which land has been distributed, it is perhaps sensible also to reflect on the core function that the institution of property fulfils in any given framework, and more specifically the redistribution discourse. If we have a clear understanding of the purpose of property and comprehend what role property should eventually fulfil for each beneficiary, we should be able to scrutinize critically the redistribution programme to make meaningful suggestions on the way forward.

The normative foundation of property is identified by Alexander as human flourishing, which is defined as the opportunity to live a life as fulfilling as possible. ${ }^{55}$ "Human flourishing is promoted by a social-obligation norm that recognizes the relational nature of human flourishing in society: to avoid selfcontradiction, we must make the same normative commitment to developing the capabilities that are required for human flourishing in others as we commit to developing in ourselves". ${ }^{56}$ Human flourishing also has a strong individualistic dimension; the very purpose of property is to allow individuals "to foster the goods of practical reason and autonomy". ${ }^{57}$ This essentially means that human flourishing cannot be achieved if individuals are denied some physical space where they can exercise the most basic activities that are vital for human survival. ${ }^{58}$

As a point of departure, it is generally accepted that property, and more specifically the ability of persons to hold property, is important for a number of reasons. As alluded to above, property enables individuals to be independent: it functions as an autonomy enhancing mechanism that allows the holder to make decisions and be politically active; the ability to hold property is directly associated with the enhancement of wealth and general wellbeing; and, above all, without property the individual would be denied opportunities to live the well-lived life, a life with self-respect and dignity. These attributes, of a life with property, can only be obtained if we acknowledge from the outset that individuals must be given some physical space where they can live, not necessarily thrive, but simply exercise the most basic activities that are vital for human survival. ${ }^{59}$ If the redistribution programme fails to address such a basic

contd

land in both the housing and redistribution discourse is not founded on the private property right of ownership. Instead, both the right of access to adequate housing and the redistribution imperative can be fulfilled by offering alternative, secure forms of tenure, such as a lease.

54 This question is discussed in more detail below.

55 Van der Walt and Viljoen "The constitutional mandate", above at note 47 at 1039, referring to GS Alexander "Property's ends: The publicness of private law values" (2014) 99 Iowa Law Review 1257 at 1260.

56 Van der Walt and Viljoen, ibid.

57 EM Peñalver "Land virtues" (2008-09) 94 Cornell Law Review 821 at 870.

58 Id at 880.

59 Such a space can be allocated in urban or rural land. The redistribution programme is mainly geared towards allocating land in rural areas. 
claim to property, which is arguably the case, it calls into question the egalitarian ethos on which the Constitution claims to be founded.

\section{REDISTRIBUTION IN SOUTH AFRICA: A CRITICAL APPRAISAL Introduction}

In 1989, Derek van der Merwe argued (with reference to Rawls's difference principle of justice) that the South African land reform policy should be guided by the principle that access to land should be fair and not necessarily equal. ${ }^{60}$ From a global perspective, the overarching objective of land reform is to address widespread inequality and reduce poverty. ${ }^{61}$ This goal is often supplemented by a range of other goals, including the advancement of outputs and greater efficiency in the agricultural sector. ${ }^{62}$ Regardless of these additional objectives, convincing arguments have been put forward to suggest that the mere provision of stable, secure access to land fosters conditions for improved livelihoods and living conditions. ${ }^{63}$ In theory, a successful land reform programme will not only benefit specific, targeted beneficiaries and their households, but also an entire community or region due to large-scale poverty reduction. ${ }^{64}$

This global objective, as well as the difference principle as contextualized by Van der Merwe, is arguably echoed in the 1997 White Paper on South African Land Policy (1997 White Paper) in "translat[ing] the government's commitment to social justice and the alleviation of poverty into a set of concrete land reform and land development programmes, legislation and procedures". ${ }^{65}$ More specifically, the 1997 White Paper stipulates that the redistribution programme is intended to provide the poor with land, to be utilized for residential and productive purposes, in order ultimately to improve their livelihoods. ${ }^{66}$ The redistribution objective is cemented in section 25(5) of the Constitution, which it provides that, "[t]he state must take reasonable legislative and other measures, within its available resources, to foster conditions which enable citizens to gain access to land on an equitable basis". ${ }^{67}$

60 D van der Merwe "Land tenure in South Africa: A brief history and some reform proposals" 1989 Journal of South African Law 663 at 690.

61 JM Pienaar Land Reform (2014, Juta) at 23 and the sources cited there.

62 Id at 24

63 RL Prosterman and T Hanstad "Land reform in the twenty-first century: New challenges, new responses" (2006) 4 Seattle Journal for Social Justice 763 at 769.

64 Pienaar Land Reform, above at note 61 at 27.

65 White Paper on South African Land Policy (1997) at 4, available at: <https://www.gov.za/s ites/default/files/gcis_document/201411/whitepaperlandreform.pdf> (last accessed 4 March 2021).

66 Id at 60. See also M Robertson "Land reform: South African options" (1989) 21 Columbia Human Rights Law Review 193 at 208-09 for the argument that land reform in South Africa should strive to provide each person with property that meets the essential needs of decent living, to maintain the dignity of the individual and his / her home. When the apartheid era came to an end, 60,000 white farmers owned more than $85 \%$ of 
Pienaar points out that the redistribution programme forms part of the state's effort to address present-day inequalities, which can be ascribed to preconstitutional policies. ${ }^{68}$

The redistribution programme is intended to make a significant contribution to address land inequalities, in addition to improving the distribution of other resources. Redistribution is centred on the principle of fairness; it is only fair, and reasonable, that all citizens should have access to land and for this reason alone access to land must be ensured. With reference to the 1997 White Paper, Pienaar explains that redistribution is inherently linked to individuals' livelihoods, means of survival and the overall eradication of poverty, although these are at least the considerations that formed the outline of the initial policies. ${ }^{69}$ The redistribution of assets has been a prominent topic for debate and important forms of redistribution have been implemented, including increased government spending on welfare services for the poor. ${ }^{70}$ Nevertheless, these measures have "had remarkably little impact on overall income inequality or poverty". ${ }^{71}$

Lahiff explains that the redistribution of assets, specifically land, "has a special place within the discourse on redistribution, both in South Africa and internationally". ${ }^{72}$ Land is not only a symbol of restorative justice, ${ }^{73}$ it also provides a place where beneficiaries can build a shelter and produce food. ${ }^{74}$ Proper redistribution of land will likely address not only landlessness but also hunger. ${ }^{75}$ Moreover, "land represents wealth, equity, and a source of control and power. Redistributing rural land will empower Africans by giving them control over a source of capital and, therefore, more control over their lives. The unique value of property lies in its conceptual essence ... For many Africans, access to land is considered to be a birthright. Land is the site of family, history, and gravesites; it is not simply a commercial asset". ${ }^{76}$

contd

the land: $M$ Antsey "Negotiating elusive justice: Dilemmas of land distribution in Southern Africa" (2019) 40 Obiter 240 at 249.

68 Pienaar Land Reform, above at note 61 at 273.

69 Id at 274.

70 E Lahiff "Redistributive land reform and poverty reduction in South Africa" (2007) Programme for Land and Agrarian Studies 1 at 8.

71 Ibid.

72 Ibid. LG Robinson "Rationales for rural land redistribution in South Africa" (1997) 23 Brooklyn Journal of International Law 465 argues (at 484) that land should be distributed as a means of compensating Africans for the harm that they suffered during the apartheid era.

73 Robinson, id at 488.

74 Id at 485 .

75 Id at 493.

76 Id at 485 and 489. 


\section{Redistribution: A policy overview}

Policies pertaining to the acquisition of land

From a policy perspective, the redistribution programme initially operated on the basis that eligible persons, as well as groups, could acquire a settlement / land acquisition grant (SLAG) to a maximum value of R16,000 per household to purchase land directly from willing sellers. ${ }^{77}$ Households earning less than R1,500 per month were eligible under section 4 of the 1997 White Paper. ${ }^{78}$ Redistribution involved a single, flexible mechanism that was accessible to a wide range of beneficiaries, including the very poor; it was dependent "upon voluntary transactions between willing-buyers and willing-sellers" and the power of the state to expropriate land for redistributive efforts was earmarked "as an instrument of last resort". ${ }^{79}$ SLAGs were essentially demanddriven, in that the state made fixed grants available to self-selected beneficiaries; the state was not involved in the acquisition and redistribution of land. ${ }^{80}$ The grants were small, which led to: the "rent-a-crowd" syndrome, in that beneficiaries were forced to pool their resources in order to purchase land; and a shortage of funding that could be used to acquire materials and build houses. ${ }^{81} \mathrm{~A}$ number of issues arose subsequent to the introduction of the initial redistribution efforts, including: the high failure rate of projects undertaken by large groups; ${ }^{82}$ the lack of contributions from applicants made it difficult to evaluate them; and the means test disqualified emerging commercial farmers. ${ }^{83}$ The handover of large-scale, productive farms to the poor, with basically no state involvement, was not only unique to South Africa's redistribution programme, but also proved to be unsuccessful. ${ }^{84}$

In 2001, SLAGs were succeeded by the Land Redistribution and Agricultural Development Policy (LRAD), which introduced more market-based agriculture,

Pienaar Land Reform, above at note 61 at 207. The amount of R16,000 was later increased to $\mathrm{R} 17,500$.

78 Above at note 65 at 91.

79 Id at 61.

80 R van den Brink, G Thomas and H Binswanger "Agricultural land redistribution in South Africa: Towards accelerated implementation” in L Ntsebeza and R Hall (eds) The Land Question in South Africa (2007, HSRC Press) 152 at 175.

81 Pienaar Land Reform, above at note 61 at 218. For examples of SLAG projects, see specifically M Aliber and B Cousins "Livelihoods after land reform" (2013) 13/1 Journal of Agrarian Change 140, available at: <https://freecourseware.uwc.ac.za/bitstream/handle /10566/3031/Aliber_Livelihoods-after-land_2013.pdf?sequence=1\&isAllowed=y $>$ (last accessed 6 April 2021) 1 at 7-9.

82 The state has pointed out that many redistributed farms "lie fallow or fail, and their new owners may seek to sell them. It is estimated by the government that up to $30 \%$ of land already redistributed has found its way back into white hands": Antsey "Negotiating elusive justice", above at note 67 at 250 .

83 Pienaar Land Reform, above at note 61 at 223.

84 Lahiff "Redistributive land reform", above at note 70 at 10 . In November 2005, for instance, the minister of agriculture and land affairs confirmed that 70 of the land reform projects in Limpopo were non-functional: id at 32. 
coupled with grants for sustainable agriculture. ${ }^{85}$ The LRAD initiated a shift from the landless poor to greater agricultural production, with distinct emphasis placed on the establishment of a class of black commercial farmers. ${ }^{86}$ The SLAG income ceiling was removed, which meant that the very poor had to compete with the not-so-poor. Similar to SLAGs, the LRAD was more accessible to the "educated, technically proficient and resourced person". ${ }^{87}$ The LRAD indicated a significant shift in the target group for redistribution, away from the vulnerable in favour of emergent farmers. ${ }^{88}$

The Proactive Land Acquisition Strategy (PLAS) was introduced in 2006 with the aim of redistributing five million hectares of white-owned land to 10,000 new farmers, thereby increasing black ownership. Contrarily, the Department of Land Affairs adopted an approach of acquiring land, subsequently to lease it to beneficiaries for a period of three years. Pienaar explains that the "programme is specifically aimed at commercial farming and profits and does not assist, generally, in broadening access to land for residential or recreational purposes. It is generally not pro-poor because it is designed to suit those who have the financial resources and knowledge base to farm commercially". ${ }^{89}$ Even though PLAS is intended to shift some of the responsibility for acquiring land to the state and to speed up redistribution, it remains hampered by the fact that it is not streamlined to assist the poor in acquiring much needed land. Nevertheless, the state-led approach should still be encouraged and "linked to concentrated purchase efforts where particular areas or regions may be identified for land purchase". ${ }^{90}$

A noteworthy problem with the land reform policies, in general, was the lack of tools that were being made available for persons who required land for either residential or recreational purposes. ${ }^{91}$ Landless persons are not necessarily all queuing for land, more specifically agricultural land for farming purposes, although the restrictive nature of the policies might lead to the situation where individuals are forced to apply for grants to achieve access

85 Lahiff argues that the LRAD is neither demand-led nor supply-led and therefore undermines the market-based principles it claims to promote: E Lahiff "Land reform in South Africa: Is it meeting the challenge?" (2001) Institute for Poverty, Land and Agrarian Studies Policy Brief 1 at 5.

86 Pienaar Land Reform, above at note 61 at 218.

87 Id at 223. See also Aliber and Cousins "Livelihoods after land reform", above at note 81 at 12-13 for an example of an LRAD project.

88 Lahiff "Redistributive land reform", above at note 70 at 19.

89 Pienaar Land Reform, above at note 61 at 219, citing L Naidoo "Poverty and insecurity of farm workers and dwellers in post-apartheid South Africa" in P Hebinck and C Shackleton (eds) Reforming Land and Resource Use in South Africa (2011, Routledge) 188 at 196.

90 Pienaar, id at 372.

91 Id at 224-25, referring to W Beinart "Strategies of the poor and some problems of land reform in the Eastern Cape in South Africa" in T Chesters (ed) Land Rights (2009, Oxford University Press) 177. 
to agricultural land, simply to acquire some land. ${ }^{92}$ A number of additional policy measures were introduced, such as the Comprehensive Agricultural Support Programme, which provides a one-off grant as post-settlement support for land reform beneficiaries. ${ }^{93}$ Even though post-settlement support has been identified as a key weakness, the inept design of most of the projects suggests that enhanced post-settlement support will not necessarily contribute to resolving the problems faced by land reform beneficiaries. ${ }^{94}$

In October 2012, a Policy Framework for Land Acquisition and Land Valuation was published, directly resulting from the identified need to address the lingering issue of acquiring suitable land for redistributive purposes. ${ }^{95}$ The central aim of the policy is to "enhance the state's capacity to realise fair value from its efforts to acquire, dispose and manage land for land reform". ${ }^{96}$ The willing-buyer-willing-seller principle is specifically identified as a concern, which has arguably led to speculative behaviour by landowners, resulting in escalated land prices. ${ }^{97}$ The policy proposes that government should abolish the willing-buyer-willing-seller principle, with immediate effect, and make more use of its power to expropriate land for redistributive purposes. ${ }^{98}$ The Joint Constitutional Review Committee was subsequently tasked to identify necessary amendments for the Constitution to permit expropriations without compensation. ${ }^{99}$ Even though this idea has sparked widespread debate among politicians, academics and the public at large, it does not form part of a distinct redistribution policy. The possibility of expropriating land without having to pay compensation has crystalized in legislative propositions, but not in the form of a policy. ${ }^{100}$

In January 2020, the Department of Agriculture, Land Reform and Rural Development published for public comment the Beneficiary Selection and Land Allocation Policy, ${ }^{101}$ which is intended to address beneficiary selection in accordance with the allocation of appropriate land. Vulnerable groups,

92 Pienaar, id at 225

93 B Atuahene "South Africa's land reform crisis: Eliminating the legacy of apartheid" (2011) 90 Foreign Affairs 121 at 125 argues that resettled land reform beneficiaries should be provided with access to capital, infrastructure and training, which requires significant state resources.

94 Lahiff "Redistributive land reform", above at note 70 at 31. Studies show that land reform beneficiaries experience a range of challenges, including access to credit.

95 Department of Rural Development and Land Reform "A policy framework for land acquisition and land valuation in a land reform context and for the establishment of the Office of the Valuer-General" (18 October 2012).

96 Pienaar Land Reform, above at note 61 at 249.

97 Department of Rural Development and Land Reform "A policy framework", above at note 95 at 10 .

98 Ibid.

99 Parliament Announcements, Tablings and Committee Reports No 169/2018 (15 November 2018) at 4.

100 The proposed legislative amendments are discussed below.

101 (3 January 2020) Government Gazette 42939. 
including smallholder producers, women and rural and peri-urban residents, are specifically earmarked as intended beneficiaries. Interestingly, the draft policy is not restricted to the allocation of land for farming purposes, it also envisions that certain individuals can apply for land if they simply intend to use the land for small-scale production, such as grazing. It therefore seems that the policy will allow for land, in an array of environments, including the urban periphery, to be distributed for subsistence farming. ${ }^{102}$

\section{A critical appraisal}

In consideration of the development of the range of policies that were introduced over the past couple of decades, it is noteworthy that a gradual shift took place from an initial focus on the needs of the poorest of the poor (in ensuring that they can access land), towards addressing the needs of the more resourced and competent beneficiaries. In due course greater emphasis was placed on commercial farming and overall efficiency. ${ }^{103}$ Even though the initial White Paper on Reconstruction and Development Programme was intended to promote principles of redistributive justice, this objective was quickly tempered by other, opposing economic approaches, such as the neoliberalist approach that was implemented at the time. ${ }^{104}$ Marais explains that "neo-liberalism depicts a retreat of the state from its social provisioning and regulatory duties in favour of the 'invisible hand' of the market". ${ }^{105}$ A neoliberalist approach is characterized by minimal state interference and the safeguarding of existing property rights. ${ }^{106}$ This approach, considered with the two economies theory, ${ }^{107}$ collectively established South Africa's approach to markets in general, and redistribution in particular. A market-based redistribution programme was therefore adopted, under which the state played a limited, facilitative role. ${ }^{108}$ It does however seem that the more recent policy initiatives, such as the Beneficiary Selection and Land Allocation Policy, as well as PLAS to some extent, have gradually redirected the state's approach to focus on the vulnerable and poor, with greater emphasis being placed on the state's role in facilitating the acquisition and allocation of suitable land for land reform purposes.

To date, the redistribution programme has largely been unsuccessful as a poverty alleviation scheme due to: it following a demand-led approach; the

\footnotetext{
102 Id at 8.4 and 8.5 .

103 Pienaar Land Reform, above at note 61 at 275.

104 Id at 277.

105 H Marais South Africa Pushed to the Limit (2011, Juta) at 134.

106 Pienaar Land Reform, above at note 61 at 278, citing L Ntsebeza "Land redistribution in South Africa: The property clause revisited" in Ntsebeza and Hall (eds) The Land Question, above at note 80, 107 at 126.

107 For a more detailed discussion, see T Mbeki "Address to the National Council of Provinces" (11 November 2003), available at: <https://www.sahistory.org.za/archive/ address-national-council-provinces-11-november-2003> (last accessed 4 March 2021); and Marais South Africa Pushed, above at note 105 at 278.

108 Pienaar Land Reform, above at note 61 at 279.
} 
way in which the grant system is set up; and the target group, ie the beneficiaries who eventually receive suitable land. ${ }^{109}$ Especially with reference to the SLAG system, too many obstacles existed for the poor to access the system and remain active beneficiaries of it. Moreover, if redistribution is intended to contribute towards poverty alleviation, it should not only target the poor but also "provide additional support, mechanisms and services to remove or alleviate existing barriers". ${ }^{110}$ The initial objectives that were underpinned in the 1997 White Paper were never put into effect, whereas the provision of small-scale land parcels for food production never featured as a viable possibility; instead, the Department of Land Affairs chose to discourage them. ${ }^{111}$ The gradual shift in policy has largely been understated and unacknowledged, although traces of it can be found in "unofficial" publications, such as ministerial speeches. There has been a virtual disappearance of any discussions relating to the way in which redistribution can or should contribute to poverty alleviation or food production on small-scale land parcels for the poor. ${ }^{112}$

With reference to economic justice theories, ${ }^{113}$ it is perhaps also safe to say that South Africa's approach to the redistribution imperative has shifted from being egalitarian (in favour of greater access to land for a wide range of individuals) to libertarian (promoting the free market in favour of an elitist group of emerging farmers, while protecting landowners' rights, almost absolutely). From a policy point of view, the redistribution programme not only resembles notions of a libertarian take on distributive justice, it generally also fails to offer a clear understanding of the function to which the redistributed property should be put. ${ }^{114}$ Initially, the idea was that land could be used for either farming or residential use, and that the redistribution of smaller parcels should also form part of the programme. This objective is in line with the notion that property should ideally allow the holder to be more independent and live an autonomous life. Even though smaller parcels of land are more suited for something like subsistence farming, rather than large-scale production, it might be more prudent to redistribute them to beneficiaries who are either not interested in commercial farming or not equipped to farm in a commercial fashion. The provision of small-scale parcels of land can also act as a vehicle for wealth creation, although it would be on a smaller scale than for a large commercial enterprise.

109 FJ Zimmerman "Barriers to participation of the poor in South Africa's land redistribution" (2000) 28 World Development 1439 at 1450-55. See also Lahiff "Redistributive land reform", above at note 70 at 2.

110 Pienaar Land Reform, above at note 61 at 373.

111 Lahiff "Redistributive land reform", above at note 70 at 17.

112 Id at 18. This is at least the position before the introduction of the Beneficiary Selection and Land Allocation Policy, which is currently published as a draft policy.

113 See the detailed discussion above.

114 The Beneficiary Selection and Land Allocation Policy can offer a new approach in this regard; to streamline beneficiaries' needs with suitable land allocation, although the efficiency of this would depend on the active involvement of the state. 
The way in which land should be utilized in terms of the redistribution programme changed when the focus shifted to the acquisition of large-scale farms in terms of SLAGs as well as the LRAD. With the introduction of SLAGs, land reform beneficiaries were effectively forced to farm together, which impacted their independence and ability to lead autonomous lives. It seems that SLAGs, as well as the LRAD, focused on wealth creation by way of greater agricultural production at the cost of providing widespread access to land for the landless and those most in need, and the beneficiaries' ability to lead self-governing lives. A critical loophole in the policy framework, created by the SLAG programme and the LRAD, is the absence of a distinct aim to provide the vulnerable and poor with some physical space where they can exercise the most basic activities that are vital for human survival.

\section{Legislative overview of mechanisms to acquire and distribute land}

A number of laws were enacted to give effect to the redistribution mandate. Most noteworthy for the purposes of this article is the Land Reform: Provision of Land and Assistance Act 126 of $1993 .{ }^{115}$ The aim of this act is to regulate the designation of land, the subdivision of land for the settlement of beneficiaries and the rendering of financial assistance for the acquisition of land. ${ }^{116}$ Once a landowner has made land available for redistribution, the minister of rural development and land reform may designate that land for settlement purposes ${ }^{117}$ and it will be exempt from the laws that regulate the subdivision of land. Interestingly, the development of the land is usually undertaken by the landowner or another private person, not the state. The developer will subdivide the land, after which the smaller portions of land will be made available for small-scale farming, residential, public, community or business purposes. ${ }^{118}$ Once the plans have been approved and filed at the deeds registry, the redistribution phase commences with the alienation (or lease) of those parcels to land reform beneficiaries. ${ }^{119}$ Even though a landowner can make his or her land available for redistribution, section 10 of the act also empowers the minister to acquire property for the purposes of the act or provide financial assistance to persons in order to further the goals of the act. Importantly, the minister has powers under the act that are similar to those that ministers have under the Expropriation Act 63 of 1975..$^{120}$

Pienaar points out that both the Extension of Security of Tenure Act 62 of 1997 (ESTA) and the Land Reform (Labour Tenants) Act 3 of 1996 (Labour

115 The act was originally known as the Provision of Certain Land for Settlement Act 126 of 1993.

116 The long title of the act sets out these objectives.

117 Land Reform: Provision of Land and Assistance Act 126 of 1993, sec 2(1)(c) and (2).

118 See id, secs 6-7 for the procedural requirements that must be met before the subdivision is approved.

119 Id, secs 7(b) and 8(1).

120 Id, sec 12(1). 
Tenants Act) are relevant in the context of redistribution. However, the reach of these laws is severely curtailed because they only apply in rural areas ${ }^{121}$ where the beneficiary is either an occupier (for the purposes of ESTA) ${ }^{122}$ or a labour tenant (for the purposes of the Labour Tenants Act). ${ }^{123}$ Under ESTA, access to land can be broadened by way of: an on-site development, which "provides occupiers with an independent tenure right on land on which they resided at the time the application was lodged or where they resided previously"; ${ }^{124}$ or an off-site development, being a development that provides occupants with tenure rights on land that is owned by a third party. ${ }^{125}$ Alternatively, the minister can make monies available to enable occupiers to acquire land or rights in land and enable the development of land for the purposes of the act. ${ }^{126}$ Access to land can be broadened for labour tenants if they apply for an award of: the land that they occupy; the land that their family occupied; rights in land elsewhere on the farm; or other compensatory land. ${ }^{127}$

In addition to these laws, one should be mindful of two further considerations in the context of the redistribution imperative, namely the distribution of state land and the interplay between land and housing. In principle, state land can be utilized for redistribution. Even though the state is one of the largest landowners in the country, ${ }^{128}$ only 2 per cent of state land is suitable for redistribution. Nevertheless, local authorities can identify and acquire suitable land for redistribution, by way of the open market, expropriation or private donations. ${ }^{129}$ On the other hand, the government is constitutionally obliged to fulfil the right of access to adequate housing and "[a]ccess to land for the purpose of housing is therefore included in the right of access to adequate housing in section 26"130 of the Constitution. However, the Department of Agriculture, Land Reform and Rural Development generally does not provide land for settlement purposes, especially not in urban areas. ${ }^{131}$ This has

121 ESTA is further curtailed because it only applies in rural (or peri-urban) areas where land is used for agricultural purposes: sec 2 .

122 See id, sec 1.

123 See Labour Tenants Act, sec 1.

124 Pienaar Land Reform, above at note 61 at 303.

125 ESTA, sec 1.

126 Id, sec 4(1).

127 Id, sec 16.

128 According to the land audit report, the government owns 17 million hectares of land, trusts own more than 23 million hectares of land, white individuals own more than 26 million hectares of land and black persons own just over one million hectares of land. It has also been pointed out that these figures "misrepresent actual racial distribution and control of the land": Antsey "Negotiating elusive justice", above at note 67 at $249-50$.

129 See also Robinson "Rationales for rural land", above at note 72 at 501.

130 Grootboom, above at note 20, para 35.

131 See specifically also the Advisory Panel on Land Reform and Agriculture Final Report (4 May 2019) for its emphasis on rural land. 
resulted in some confusion regarding who is responsible for the needs of the urban poor "whose priority is not formal housing but a plot of land on which to erect a basic shelter". ${ }^{132}$

Finally, the legislative propositions that were introduced to make way for expropriations at a cost of nil compensation are also important measures that aim to promote greater access to land. It is however not clear where this option would fit into the land reform framework, because it has not been explained in terms of a specific government policy. A movement away from the market-led approach to allow for more involvement from the state in acquiring well-located, suitable land should probably be located under the redistribution programme, because it is essentially concerned with the reallocation of land rights. In December 2018, the minister of public works released the Draft Expropriation Bill, $2019^{133}$ for public comment; this bill would permit the state to expropriate land in certain instances without having to pay compensation. Its reach is restricted to the expropriation of land, not any other type of property. ${ }^{134}$

In December 2019 came the Draft Constitution Eighteenth Amendment Bill,135 which intends to amend the Property Clause "so as to provide that where land and any improvements thereon are expropriated for the purposes of land reform, the amount of compensation payable may be nil". ${ }^{136}$ The point of departure is that the state should still compensate expropriated landowners, although, if land is expropriated for land reform purposes, a court may permit nil compensation to be paid, provided that it is authorized in dedicated legislation. One should subsequently scrutinize the underlying reason for the amendment, which is arguably to do away with a compensation requirement in the context of land reform expropriations. ${ }^{137}$ This requirement has been blamed for the failure of land reform, and more specifically the redistribution programme, although the overview of the relevant policies clearly indicates otherwise.

132 Lahiff "Land reform", above at note 85 at 6.

133 (21 December 2018) Government Gazette 1409. See specifically sec 12(3) of the bill. The Expropriation Bill followed on 9 October 2020 (Government Gazette 43798) and sec 12(3) allows for land to be expropriated for nil compensation, provided that is just and equitable.

134 See specifically S Viljoen "Expropriation without compensation: Principled decisionmaking instead of arbitrariness in the land reform context (part 1)" (2020) Journal of South African Law 35 at 36-39, read with the Constitution, sec 36.

135 A copy of the bill is available at: <https://www.parliament.gov.za/storage/app/media/Co mmitteeNotices/2019/december/06-12-2019/Draft_advertised.pdf> (last accessed 4 March 2021).

136 Draft Constitution Eighteenth Amendment Bill, preamble. Interestingly, the bill allows for land to be expropriated for nil compensation, although the purpose of the expropriation does not have to be land reform.

137 Viljoen "Expropriation without compensation", above at 134 at 39. 


\section{Identifying gaps, obstacles and incongruities}

The disconnect between policies and laws

A central problem with the South African redistribution approach is the fact that "the actual redistribution tools are usually not set out in the overarching legislation as such, but are found in the detail of policy and other supplementary documents". ${ }^{138}$ Another problem is the inexplicable divide between the policies and the laws. ${ }^{139}$ The aim of the 1997 White Paper was partly to redistribute land to the poor to eradicate poverty; redistributed land could be utilized for either small-scale farming or residential purposes. This approach shifted when the SLAGs were introduced, as greater emphasis was placed on the acquisition of productive farms by way of a grant system, forcing land reform beneficiaries to pool their grants and farm together. The LRAD signalled another distinctive step away from the initial redistribution mandate; more emphasis was placed on large-scale commercial farming, which was mainly reserved for the better-off black farmers. Considered together, these policy measures are demand-driven in the sense that a land reform beneficiary should take the required initiative, and responsibility, to acquire suitable land through the grant system. ${ }^{140}$ The policies are also market-led, because the availability of land is largely dependent on landowners' willingness to sell. The state merely facilitates this process by providing grants; it is by no means involved in the acquisition or distribution of land parcels.

In stark contrast to these policies, the Provision of Land and Assistance Act, which is arguably intended to play a fundamental role in facilitating greater access to land, is founded on the idea that the minister should designate land for development purposes, after which private developers should develop parcels of land for small-scale farming or residential purposes. There is therefore a clear disconnect between the overarching purposes of the policies (specifically the SLAG and LRAD) and this act: the policies are structured to promote access to commercially viable farms, whereas the act facilitates access to land for small-scale farming and residential purposes. ${ }^{141}$ It is also not clear how land reform beneficiaries are supposed to utilize their grants, acquired as a SLAG or under the LRAD, in the context of the act. Even though ESTA and the Labour Tenants Act fall under the redistribution mandate, the application of both acts is limited to existing ESTA occupiers or labour tenants; they are not geared to facilitate wide-scale access to land. More specifically, the operation of these laws is clearly detached from these policies because they allow ESTA

138 Pienaar Land Reform, above at note 61 at 334.

139 This was confirmed in Rakgase and Another $v$ Minister of Rural Development and Land Reform and Another 20201 SA 605 (GP), para 5.4.3.

140 The Beneficiary Selection and Land Allocation Policy is also founded on a demand-led system. The applicant should lodge an application for land, which will be considered on the basis of the criteria.

141 Even though PLAS is founded on the state being involved in acquiring and distributing land, its reach is restricted to more affluent black farmers; it is not intended to assist the vulnerable and poor in acquiring land. 
occupiers or labour tenants to acquire a small piece of land for, one would assume, subsistence farming or residential use, rather than large-scale land for commercial farming (as intended under the SLAG and LRAD regimes). ${ }^{142}$

\section{The acquisition of land}

One of the most contentious issues of the redistribution programme is the manner in which suitable land should be identified, acquired and transferred on a large enough scale. From the outset, the state opted for a market-based approach, founded on the willing-buyer-willing-seller principle, which relies on voluntary agreements between private persons. The price of land is also determined with reference to the free market, whereas the state is largely uninvolved in the negotiations as well as the final transaction. Lahiff explains that the concept of "willing seller" protects the interests of existing landowners, in an absolute fashion, whereas no such guarantees are provided to would-be beneficiaries, "who continue to depend on state approval of their grant applications and the willingness of owners to transact with them". ${ }^{143}$

As opposed to a state-led system, the market-based approach was in line with both negotiated land reform as well as the principles of reconciliation and nation building. ${ }^{144}$ The willing-buyer-willing-seller principle was the result of a policy choice, not a constitutional principle. The market-based approach has given rise to a number of problems, most noteworthy being the difficulty experienced by beneficiaries in acquiring suitable land on the open market: land that is placed on the market is often unsuitable for beneficiaries' needs; prices seem to be inflated; ${ }^{145}$ and bureaucratic delays are largely met with frustration and scepticism. ${ }^{146}$ The programme has generally failed to release adequate land onto the open market. Part and parcel of the willing-buyer-willing-seller principle is the demand-led approach, which entails potential buyers taking the initiative to acquire land: responsibility for initiating land reform projects effectively does not rest with the state. ${ }^{147}$ The supply of land is therefore left to the "invisible hand" of the market,

142 The laws that strengthen tenure rights of ESTA occupiers and labour tenants contribute to the redistribution discourse by way of ensuring that such occupiers can continue to occupy their homes with secure tenure, therefore also enabling such households to flourish.

143 E Lahiff "From 'willing seller, willing buyer' to people-driven land reform" (2005) 17 Institute for Poverty, Land and Agrarian Studies Policy Brief 1 at 2.

144 Pienaar Land Reform, above at note 61 at 226. During the transition period, "arguments in favour of any forms of confiscation or nationalisation (without compensation) were vehemently opposed": id at 281.

145 Lahiff explains that in practice the price was often determined by professional land valuers in the department with reference to comparable sales in the vicinity: E Lahiff “'Willing buyer, willing seller': South Africa's failed experiment in market-led agrarian reform” (2007) 28 Third World Quarterly 1577 at 1585-86.

146 Pienaar Land Reform, above at note 61 at 227.

147 MC Lyne and MAG Darroch "Land redistribution in South Africa: Past performance and future policy" (2003, BASIS CRSP, University of Wisconsin-Madison) at 4-5. 
which means that the landless must identify land that was placed on the market, specifically for the purposes of redistribution, and negotiate with the landowner. This is founded on "major inequalities of power and resources between potential buyers (typically first-time buyers) and sellers (typically experienced landowners and market operators)". ${ }^{148}$

It is not surprising that the willing-buyer-willing-seller principle is being reviewed with a view to its abolition. However, its total abolition is perhaps not prudent either. Pienaar argues that a more nuanced approach is required, consisting of a range of mechanisms or approaches, including a market-based approach. ${ }^{149}$ This logic is supported by evidence showing that private transactions by black persons in some cases exceeded government-assisted purchases. ${ }^{150}$ Nevertheless, it remains clear that the government should become more involved and take responsibility for acquiring suitable land at scale. ${ }^{151}$ PLAS is therefore welcomed as a strategy that allows more involvement from the state to acquire and distribute land to beneficiaries. Landowners' remaining power over the success of the redistribution programme should however be addressed further, not only to increase the supply of land for redistribution but also to ensure that suitable land is allocated for land reform beneficiaries in areas where necessary. As already mentioned, it is highly questionable whether the proposed constitutional amendment will remedy the real issue here, namely the limited extent of the state's involvement in acquiring and distributing land for land reform purposes.

\section{The size of the land}

From a production point of view, the contribution of small-scale farmers in terms of the redistribution programme is quite limited, especially in comparison to large-scale producers. Moreover, their contribution is only limited to regional production. Land that belongs to large-scale successful landowners should therefore preferably not be transformed into small-scale landholdings for the purposes of redistribution since this may well lead to fragmentation, having an adverse effect on agricultural production as well as agricultural exports. ${ }^{152}$ Consequently, it has been argued that less successful large-scale land should be identified and transformed into small-scale land parcels for redistribution, although large-scale black farmers should also be assisted with greater access to large-scale land. ${ }^{153}$ At the same time, research has shown that households that are dependent on external assistance, such as grants, are often also in need of landholding. The argument has therefore

148 Lahiff "From 'willing seller", above at note 143 at 3.

149 Pienaar Land Reform, above at note 61 at 361.

150 Lyne and Darroch "Land redistribution", above at note 147 at 8-10 and 16.

151 Pienaar Land Reform, above at note 61 at 361.

152 Atuahene "South Africa's land reform", above at note 93 at 125-26.

153 O Olubode-Awosola, HD van Schalkwyk and A Jooste "Mathematical modeling of South African land redistribution for development policy" (2008) 30 Journal of Policy Modeling 841 at $851-53$. 
been put forward to suggest that these individuals should be assisted with the provision of some access to land, even if only in small parcels. ${ }^{154}$ The counter argument is that "if small-scale farming were to be reproduced at scale it would merely continue the pre-constitutional urban / rural divide, whereas the promotion of large-scale black farming enterprises would not only address this kind of stereotyping, but would effectively address the continued skewed land ownership pattern as well". ${ }^{155}$ Overall, there is arguably a need for both small and large parcels of land, depending on the specific circumstances. ${ }^{156}$

Empirical research shows that almost half of the intended beneficiaries require land that is smaller than one hectare, which means that the land markets should respond to this need and align the financial grant system to provide small-scale land parcels through small grants; this is not currently possible under the policy framework. ${ }^{157}$ Empirical research also suggests that, when the land reform programme was initiated, almost 70 per cent of black rural households considered themselves in need of land. Interestingly, the amount of land that they required, specifically farmland, was very small. ${ }^{158}$ The failure to subdivide land has been identified as a fundamental contributor to the underperformance of land reform projects because it imposes unsuitable land on beneficiaries; the farms are too large and beneficiaries are forced to operate in groups, which results in them having to negotiate their rights and responsibilities within group structures. ${ }^{159}$

"Effective control over productive resources, especially land and water, by the rural poor is crucial to their autonomy and capacity to construct a rural livelihood and to overcome poverty. This is largely because in many countries today a significant portion of the income of the rural poor still comes from farming". ${ }^{160}$ Land is a vital economic asset for the rural poor on the basis that it serves as both a "primary means for generating a livelihood" and a "vehicle for investing, accumulating wealth, and transferring it between generations". ${ }^{161}$ Based on these arguments, the overall suggestion is that

154 Pienaar Land Reform, above at note 61 at 348-49, referring to K Helliker "Contemporary rural realities in Southern Africa” in K Helliker and T Murisa (eds) Land Struggles and Civil Society in Southern Africa (2011, Africa World Press) 1 at 19.

155 Pienaar, id at 349.

156 The Beneficiary Selection and Land Allocation Policy might be able to fill this gap because it categorizes different types of land for diverse needs, including small-scale farming and subsistence farming in rural and peri-urban areas.

157 Pienaar Land Reform, above at note 61 at 352.

158 Lahiff "Redistributive land reform", above at note 70 at 4.

159 Id at 27. See also the Regulation of Agricultural Land Holdings Bill (17 March 2017) Government Gazette 40697, which deals with the redistribution of agricultural land. The bill is however not instructive on the subdivision of such land.

160 SM Borras Land, Empowerment and the Rural Poor: Challenges to Civil Society and Development Agencies (2006, International Fund for Agricultural Development) at 4.

$161 \mathrm{~K}$ Deininger and $\mathrm{H}$ Binswanger "The evolution of the World Bank's land policy: Principles, experience and future challenges" (1999) 14 The World Bank Research Observer 247 at 247. See also H Claxton "Land and liberation: Lessons for the creation 
small-scale land parcels should be distributed more progressively as a form of poverty alleviation.

\section{Preliminary suggestions on the way forward}

Land reform has been unsuccessful in two respects: its pace (roughly 8 per cent of commercial farmland has been redistributed); and its performance (the 8 per cent that has been redistributed has arguably not contributed to either the improvement of individuals' livelihoods or production outcomes). ${ }^{162}$ In consideration of the redistributive tools and measures mentioned above, there is an imminent need to speed up redistribution. Even though the mere distribution of land to the poor will not automatically enhance their livelihoods, access to suitable land will "certainly contribute to social stability and improved livelihoods. After all, land still remains the most effective safety net". ${ }^{163}$ In addition, Kepe argues that, "land carries a powerful symbolic charge for many black South Africans not only because of their recent memories of racialised dispossession of their land, but also because inequalities in land ownership 'stand for' and evoke the broader inequalities that post-apartheid policies have yet to undo". ${ }^{164}$

The entire redistribution discourse (and specifically South Africa's approach towards the distribution of land) should be realigned to egalitarian principles, which in its simplest form means that land should be distributed in an equal manner. It should be acknowledged from the outset that a right exists in every previously disadvantaged person to have his basic land needs met by the South African government and this right is one of justly held property. The equal distribution of land is also a vital component of South Africa's ongoing commitment to correct past injustices, but some consensus is needed about what should in fact be distributed to adhere to the constitutional mandate. In some instances, the SLAG, LRAD and PLAS regimes are perfectly well suited to black farmers' needs where agricultural land is required to farm productively. The literature does however leave a significant question as to the extent to which these policies are able to respond to the land needs of the masses. Arguably, a significant percentage of the landless require nothing more than a physical space where they can exercise the most basic activities for human survival. Apart from the 2020 Beneficiary Selection and Land Allocation Policy, which is still in draft form, none of the redistribution policies are geared towards addressing this need. The purpose of property (in the redistribution discourse explained as a secure, unfettered right to

contd

of effective land reform policy in South Africa” (2003) 8 Michigan Journal of Race $\mathcal{F}$ Law 529 at 549.

162 Aliber and Cousins "Livelihoods after land reform", above at note 81 at 1.

163 Pienaar Land Reform, above at note 61 at 375.

164 T Kepe, R Hall and B Cousins "Land" in N Shephard and S Robins (eds) New South African Keywords (2008, Ohio University Press) 143 at 145. 
hold land) is to enable human beings to participate actively in society and flourish as contributing citizens. This ideal of human flourishing cannot be achieved as a long-term objective if the landless are denied a bare, physical space in which to survive.

PLAS, read with the Beneficiary Selection and Land Allocation Policy, can arguably allow for a more interventionist approach by the state; transformation can hardly by achieved by way of piecemeal reform via the free market. Reform should preferably target areas in need, to provide adequate opportunities through an integrated approach. Even though the free market should still play a role in land reform, in general one cannot expect the market to be relied on "to deliver land in the places, at the scale and at the price required for a major national programme of transformation". ${ }^{165}$ Critical to this suggestion is that powers should be delegated to local authorities that work directly with local communities. Municipalities are arguably best suited to identify needs and provide solutions within a particular area. As mentioned by Lahiff, land reform should be decentralized to allow for a range of land reform programmes, specific to municipal areas. ${ }^{166}$ In addition, widespread expropriation is not necessary; instead, selective expropriations that form part of a rigorous land acquisition strategy should suffice to increase the supply of land for beneficiaries in areas of need. ${ }^{167}$

\section{CONCLUDING REMARKS: OPTING FOR A POLICY OVERHAUL AND LEGISLATIVE COMPLIANCE}

Redistribution is a core constitutional imperative, which should act as a vehicle for large-scale resource allocation, wealth distribution and economic justice. The underlying idea is that land should be distributed to the poor in a manner that would have an equalizing effect; this means that property should be reallocated to the masses. This is however a presumption, seemingly falsely founded on the egalitarian ethos of the Constitution. The working presumption in the context of economic justice, and more so the redistribution of land, seems to be founded on libertarian notions, rather than the "egalitarian ethos" of the Constitution. The policy overview in this article clearly shows that a market-based approach is preferred, under which the free-market reigns supreme; land holdings rarely shift in the absence of free will. This approach comes at a price, not the price negotiated by the parties, but rather the diminished scale at which land effectively moves from the haves to the have-nots. From a policy perspective, the redistribution programme is not geared to have an equalizing effect in the land market; there is also no social consensus on what is meant by distributing basic material needs in the context of land.

165 Lahiff "Land reform in South Africa", above at note 85 at 6.

166 Ibid.

167 Lahiff "From 'willing seller', above at note 143 at 2-3. On the other hand, see Dagan "Takings and distributive justice", above at note 50 at 761 . 
Stated differently, we have not established a default position, or threshold of what should ideally be distributed to the desperately poor and landless as a means of enabling them to establish their livelihoods, which can roughly be translated as a threshold for living the well-lived life, a life of meaning and purpose. Even though the state is tasked with the duty to ensure that property (serving as a necessary stepping stone for the enjoyment of other constitutional rights) should be distributed as widely as possible to allow everyone to flourish as human beings, without falling prey to subordination, the policies are not aligned to allow large-scale dispersal of access to land. Instead, the reach of the state's market-led approach is severely curtailed to enable a handful of land reform beneficiaries to acquire large-scale land to farm productively. ${ }^{168}$ In accordance with some policies, such as PLAS, where the state is more involved in the acquisition and distribution of land, the impact is restricted to affluent farmers.

An egalitarian approach should arguably be reintroduced to shift the focus back to the constitutional objective of equalizing land holding in South Africa, not only to rectify injustices of the past but also to empower the marginalized to take their rightful place as active, participating citizens. The literature rightly suggests that more land should be distributed, specifically small-scale parcels of land for a range of purposes, such as subsistence farming. This will allow beneficiaries to produce food, establish some form of shelter and in due course improve their livelihoods and living conditions. In line with what is proposed in the Draft Beneficiary Selection and Land Allocation Policy, small-scale parcels of land should arguably be provided in addition to other types of land, including large-scale parcels of land that are better suited to commercial farming. An array of options should ideally be offered to ensure that the landless can access land that is suitable for their needs, abilities and budgets.

The only way in which the redistribution imperative can truly have an equalizing effect in relation to land holding is through the implementation of a state-led approach to the acquisition and distribution of land. With reference to the former, the state should arguably embark upon widescale expropriation of well-located, suitable land for land reform purposes. The Constitution empowers the state to expropriate land for this purpose, provided that just and equitable compensation is paid. The current legislative framework allows for compensation to be paid at reduced prices, including nil compensation, which calls into question the need for the proposed constitutional amendment as well as the entire "expropriation without compensation" movement. Moreover, a number of laws that form part of the redistribution programme reiterate the state's wide-ranging power to

168 The Beneficiary Selection and Land Allocation Policy can be interpreted to offer a new approach, in that it allows land reform beneficiaries to apply for smaller plots of land in diverse areas, to be used for different purposes. This is a welcome initiative, which should be supported with more rigorous acquisition of suitable land by the state. 
expropriate land for land reform purposes. Even though the policy framework is opposed to the use of this power, neither the Constitution nor the laws that aim to give effect to its vision reflect this.

\section{CONFLICTS OF INTEREST}

None 